\title{
The Effect of Working from Home During the Covid-19 Pandemic on Human Capital Organizational Effectiveness in an Indonesian Heavy Equipment Company
}

\author{
Nasution $^{2}$ \\ ${ }^{1}$ United Tractors. Tbk., Jakarta - Indonesia \\ ${ }^{2}$ Master of Mechanical Engineering, Swiss German University, Tangerang - Indonesia \\ *Corresponding author. Email: gembong.baskoro@sgu.ac.id
}

Edhie Sarwono $^{1,2}$ Gembong Baskoro ${ }^{2, *}$ Sumarsono ${ }^{2}$ Dena Hendriana ${ }^{2}$ Henry

\begin{abstract}
The goal of this study is to determine the impact of Work from Home dimensions on Organizational Effectiveness dimensions, as well as superior and subordinate perceptions during pandemic Covid-19, by employing an inferential statistical method and descriptively empirical corporate data analysis. During the pandemic Covid-19, this study was conducted at Human Capital Organization with a 100\% sample approach (70 population) and discovered that Work from Home had a favourable link with Organizational Effectiveness. The findings of this study will be utilized to develop policies that will apply to thousands of employees in organizations with similar organizational culture, management systems, and policies. There are three more characteristics that suggest a favourable correlation: having children at home, having an internet connection at home, and having a mobile device. Further research can be conducted using the concept of local wisdom because each nation with its own culture will react differently to this phenomenal, and the conclusion of this study was useful for the organization in determining the proper policy of working methods during and after the Covid-19 pandemic to achieve organizational effectiveness.
\end{abstract}

Keywords: Work from Home, Organizational Effectiveness, Local Wisdom.

\section{INTRODUCTION}

Covid-19 pandemic disrupt many aspects of our daily life in short term, medium and also long-term basis. Our behaviors must be adapted with health mandatory requirements as a new normal for several years. Human Capital Organization is one of the very important strategic function within the company to ensure all of the employee (at operational holding company and subsidiary) are ready to well perform at any condition based on characters and competencies requirements (Indonesia Leading Heavy Equipment Company 2019 Annual report).There are five roles of human capital organization describe as follows [1]: (1) Operational Partner, (2) Organization Developer (and Cost Control), (3) Talent Transformer, (4) Agent of Change, and (5) Administration Expert.

Pandemic Covid-19 affecting organization around the world, all of us have to balance humanity and business activities, for example: combined working methods (Work from Home/WFH \& Work from Office/WFO) that impacting Organizational
Effectiveness (OE). The results of this research will be used to create policies that correlate to thousands of workers in organization, that have similar organizational culture, management system and policies.

\subsection{Research Question}

a. Does Work from Home correlate with Organizational Effectiveness?

b. Are Employee condition (Having Children at Home, Home Internet Connection, Mobile Device) correlated with Organizational Effectiveness?

c. Is there any difference perception between Superior and Subordinate toward implementation Work from Home method?

d. Is there any difference in perception between Superior and Subordinate toward OE? 


\section{LITERATURE REVIEW}

\subsection{Organization Effectiveness}

There are four dimensions to evaluate the organizational effectiveness [2], that is:

a. Purposeful: this consist of three indicators: Efficiency, Productivity, and Stability.

b. Adaptable: this is consist of three indicators: Innovation, Growth, and Evaluative.

c. Sustainable: this consist of four indicators: Fiscal Health, Output Quality, Information Management, and Conflict and Cohesion.

d. Harm minimization: this consist of two indicators: Intra and Extra Organizational.

\subsection{Work from Home Methods}

Refer to Guspa and Rahmi [3], there are 3 dimension that influence people perception, that is:

a. Cognitive: associated with thinking and or conscious mental processes. It represents the individual faith and stereotype of the object (good or bad).

b. Affective: associated with the emotions, feeling that related with the object.

c. Conative: associated with a wish, intention, or effort to do something (behavior).

\subsection{Research Paradigm}

A research paradigm is shown in Figure 1.

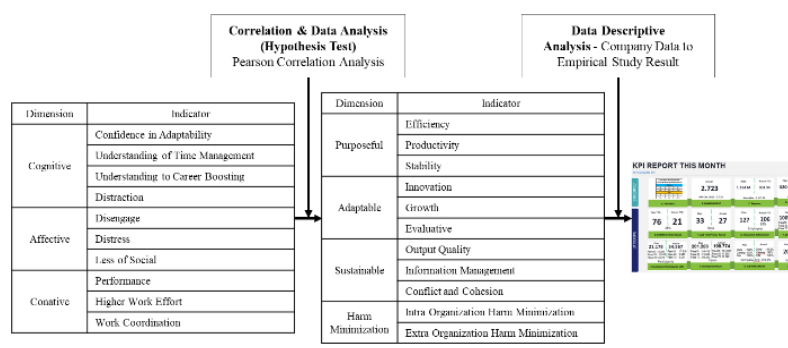

Figure 1 Research paradigm

\section{RESEARCH METHOD}

There are 2 main variables (Work from Home Perceptions as of Independent Variable and Organizational Effectiveness as of Dependent Variable) and 1 Moderate Variable to be evaluated is shown in Figure 2.

The Primary data was the result of Total Sampling method from the questionnaire distributed online (using Google form tools) to $100 \%$ of Human Capital organization employee (70 employee), from $24-25$ November 2020. Before start the hypothesis analysis, researcher conduct validity \& reliability test for check the items of questionnaire are valid or not.

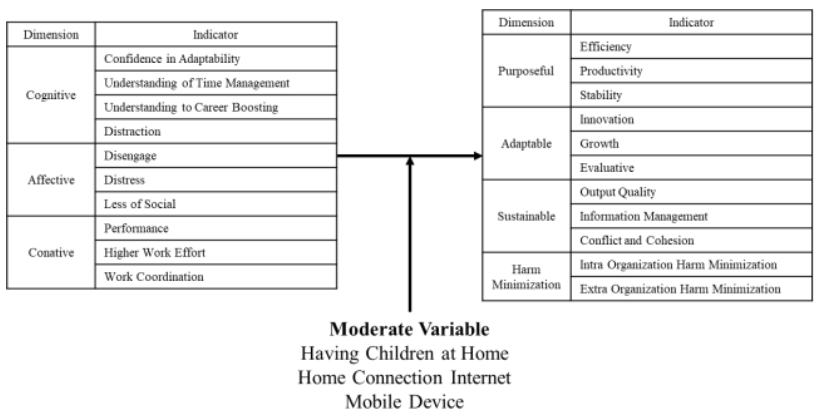

Figure 2 Research variable

\subsection{Validity Test}

There are 3 types of validity test and all of that validity test had been executed for this research: Content Validity (Professional Judgment and Face) and Construct/statistic validity. Statistics validity in this research are using statistical Pearson correlation method in SPSS (Statistical Product and Service Solution) and the validity test result of variable X (WFH Perceptions) are in $0.308-0.711$ and variable $\mathrm{Y}$ (Organizational Effectiveness) are in $0.436-0.855$. ( $r$ result $\geqslant r$ table $)$ where $r$ table is 0.231883 (as minimum reference) which mean all of the items is valid [4]

\subsection{Reliability Test}

Reliability refers to the extent to which a scale produces consistent results if repeated measurements are made [5]. The result of reliability test is 0.911 for variable $\mathrm{X}$ and 0.969 for variable $\mathrm{Y}$ which indicates every variable in the questionnaire on this study is highly reliable. For manual calculation, Cronbach Alpha formula is:

$\alpha=\frac{n}{n-1}\left(\frac{s-\sum S_{i}}{S}\right)$

where,

$\alpha$ : Reliability Coefficient / Cronbach Alpha

$\mathrm{n}$ : The number of items in the test

$\mathrm{S}$ : Overall score of variances

$\mathrm{Si}$ : The variance of each item

\subsection{Correlation Analysis}

To proof of the hypothesis between Work from Home as independent variable and Organizational Effectiveness as dependent variable, this research use Pearson correlation analysis method. Correlation analysis is used to verify and measure the strength of the 
association (linear relationship) between two variables [6].

The correlation coefficient $(r)$ can be calculated as [5]:

$r=\frac{\sum_{i=1}^{n}\left(X_{i}-\bar{X}\right)\left(Y_{i}-\bar{Y}\right)}{\sqrt{\sum_{i=1}^{n}\left(X_{i}-\bar{X}\right)^{2} \sum_{i=1}^{n}\left(Y_{i}-\bar{Y}\right)^{2}}}$

where,

$r$ : Correlation coefficient

$X_{i}$ : Values of the $\mathrm{x}$-variable in a sample

$\bar{X}:$ Mean of the values of the $\mathrm{x}$-variable

$Y_{i}$ : Values of the y-variable in a sample

$\bar{Y}:$ Mean of the values of the y-variable

\subsection{Multiple Regression}

Another one, in this research will use Multiple Regression because it can predict the value of a dependent variable based on the value of at least one independent variable and explain the impact of changes in an independent variable on the dependent variable. Multiple Regression is a statistical technique that simultaneously develops a mathematical relationship between two or more independent variables/dimension and an interval-scaled dependent variable [5].

The general form of the multiple regression model [5] is as follows:

$\mathrm{Y}_{\mathrm{i}}=\beta_{0}+\beta_{1} \mathrm{X}_{1 \mathrm{i}}+\beta_{2} \mathrm{X}_{2 \mathrm{i}}+\cdots+\beta_{\mathrm{k}} \mathrm{X}_{\mathrm{ki}}+\varepsilon_{\mathrm{i}}$

And which is estimated by the following equation:

$\hat{\mathrm{Y}}_{\mathrm{i}}=\mathrm{b}_{0}+\mathrm{b}_{1} \mathrm{X}_{1 \mathrm{i}}+\mathrm{b}_{2} \mathrm{X}_{2 \mathrm{i}}+\cdots+\mathrm{b}_{\mathrm{k}} \mathrm{X}_{\mathrm{ki}}$

where,

$\hat{\mathrm{Y}}_{\mathrm{i}}$ : Estimated Value of Y (Dependent Variable)

b0 : Estimated Intercept

biXi : Estimated Slope Coefficients

\section{RESULTS AND DISCUSSIONS}

\subsection{Results}

1. Data Analysis for $1^{\text {st }}$ Hypothesis: For the 1st hypothesis obviously had been proven that Work from Home having correlation $65.9 \%$ (Strong Correlation) with Organizational Effectiveness.

2. Data Analysis for $2^{\text {nd }}$ Hypothesis: Having Children at Home: For 1st Moderate variable summary analysis: Having Children at Home, support positive correlation between Work from Home and Organizational Effectiveness ( $\mathrm{R}$ square $=59.9 \%$ )

Home Connection Internet: Having Internet Home Connection as 2nd moderate variable, support positive correlation between Work from Home and Organizational Effectiveness ( $\mathrm{R}$ square $=50.2 \%$ )

Mobile Device: The summary analysis as follow: Having Mobile Device as 3rd moderate variable support positive correlation between Work from Home and Organizational Effectiveness ( $\mathrm{R}$ square $=34.9 \%$ ).

3. Data Analysis for $3^{\text {rd }}$ Hypothesis: Implementation of WFH influenced by perception of employee and employer or subordinate and superior. As a comparative test between these two groups to ensure if there are any significant differences, this research used the Independent-Sample T-Test method. This data analysis result $(\mathrm{T}$ Result $=1.005<\mathrm{T}$ Table $=1.9966)$ proved that there is no difference perception between Superiors and Subordinate toward implementation of Work from Home.

4. Data Analysis for $4^{\text {th }}$ Hypothesis: There is a similarity in variance between groups or which means homogeneous. Regarding to the 4th hypothesis, this data analysis result $(\mathrm{T}$ Result $=$ $2.139>\mathrm{T}$ Table $=1.9966$ ) proved that there was significant difference in perception between Superior and Subordinates toward OE.

5. Official Data of Organizational Effectiveness Analysis: To review and strengthen the analysis of correlation between Work from Home and Organizational Effectiveness, this research also conducted description analysis data for Human Capital Organization achievement using Organizational Effectiveness framework.

To Observe and analyse all data at Table 1, clear stated that almost all of the parameter of Human Capital Organization achievement was increased. It was proved that during Work from Home, activities still optimize execute and the performance also still in line with organizational planning. It is very clear and strong in real evidence and indisputable that Work from Home has a positive correlation with all Dimensions in Organizational Effectiveness. 
Table 1. Organizational achievement data based on organizational effectiveness framework

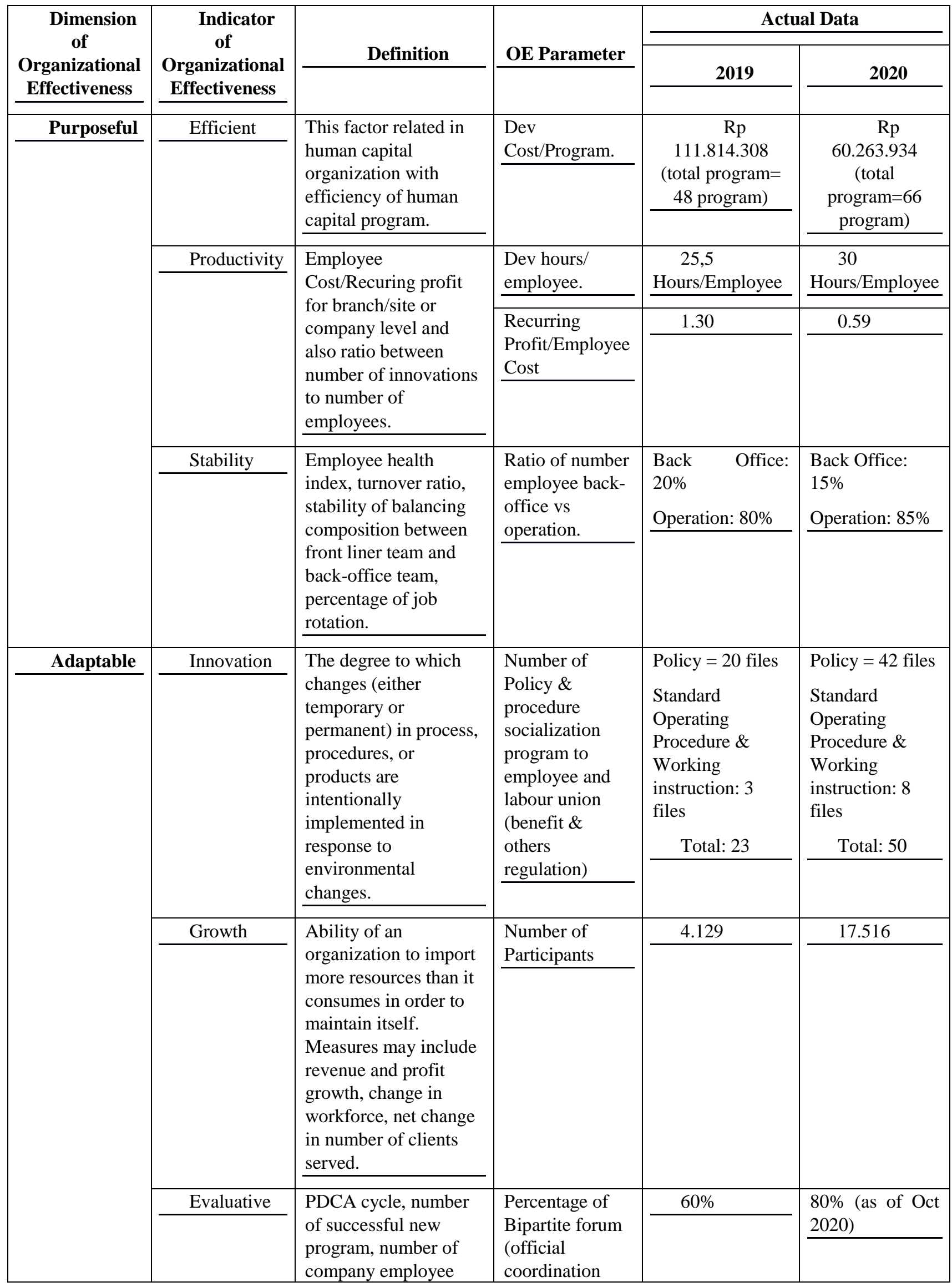




\begin{tabular}{|c|c|c|c|c|c|}
\hline & & $\begin{array}{l}\text { participation, and } \\
\text { performance } \\
\text { management system } \\
\text { implementation. }\end{array}$ & $\begin{array}{l}\text { forum between } \\
\text { management } \\
\text { and Labour } \\
\text { Union). }\end{array}$ & & \\
\hline \multirow[t]{8}{*}{ Sustainable } & Output Quality & \multirow{4}{*}{$\begin{array}{l}\text { Customer Satisfaction } \\
\text { Index (CSI), Employee } \\
\text { Engagement Index } \\
\text { (EEI) and percentage } \\
\text { of innovation winner. } \\
\end{array}$} & \multirow{4}{*}{$\begin{array}{l}\text { Number of } \\
\text { innovation } \\
\text { winner. }\end{array}$} & \multirow{4}{*}{$\begin{array}{l}1 \text { Team } \\
\text { (Corputown) } \\
\text { Internal Award } \\
\end{array}$} & \multirow{4}{*}{$\begin{array}{l}\text { - } 2 \text { Team (Flexy } \\
\text { Benefit \& } \\
\text { UT One) } \\
\text { For Internal } \\
\text { Award } \\
\text { - } 3 \text { Teams for } \\
\text { external } \\
\text { award (HR } \\
\text { Excellence } \\
\text { Award) } \\
\text { - 1 Leader for } \\
\text { external } \\
\text { award (HR } \\
\text { Future } \\
\text { leader } \\
\text { award) }\end{array}$} \\
\hline & & & & & \\
\hline & & & & & \\
\hline & & & & & \\
\hline & Information & \multirow[b]{2}{*}{$\begin{array}{l}\text { Cross level } \\
\text { collaboration, } \\
\text { accessibility to } \\
\text { influence, participative } \\
\text { and involvement in } \\
\text { decision making, and } \\
\text { communications } \\
\text { processes inside and } \\
\text { external to the } \\
\text { organization. } \\
\end{array}$} & \multirow{2}{*}{$\begin{array}{l}\text { Lead time of } \\
\text { Management } \\
\text { Documentation } \\
\text { Development } \\
\text { (Policy, memo, } \\
\text { procedure, work } \\
\text { instruction, } \\
\text { etc.). } \\
\end{array}$} & \multirow[t]{2}{*}{7 Days } & \multirow[t]{2}{*}{ 4 Days } \\
\hline & & & & & \\
\hline & Conflict \& & \multirow{2}{*}{$\begin{array}{l}\text { Quantity of cross } \\
\text { function coordination, } \\
\text { number of conflict. }\end{array}$} & \multirow{2}{*}{$\begin{array}{l}\text { Number of } \\
\text { working team } \\
(\mathrm{HC})\end{array}$} & 7 & \multirow[t]{2}{*}{32} \\
\hline & Cohesion & & & & \\
\hline \multirow{8}{*}{$\begin{array}{c}\text { Harm } \\
\text { Minimization }\end{array}$} & Good & \multirow{5}{*}{$\begin{array}{l}\text { Ethical and legal items } \\
\text { that pertain to matters } \\
\text { internal to the } \\
\text { organization such as } \\
\text { instances of ethical } \\
\text { conduct breach, } \\
\text { evidence of workforce } \\
\text { training, and internal } \\
\text { and external audits. }\end{array}$} & \multirow{5}{*}{$\begin{array}{l}\text { Environment } \\
\text { Health \& Safety } \\
\text { Audit (AGC) } \\
\end{array}$} & Gold: 24 & \multirow{5}{*}{$\begin{array}{l}\text { Gold: } 35 \\
\text { Green: } 7 \\
\text { Blue: } 1 \\
\text { Red: } 0 \\
\end{array}$} \\
\hline & $\begin{array}{l}\text { Governance } \\
\text { (Internal) }\end{array}$ & & & Green:19 & \\
\hline & & & & Blue: 0 & \\
\hline & & & & Red: 1 & \\
\hline & & & & & \\
\hline & Good & \multirow{3}{*}{$\begin{array}{l}\text { Ethical and legal items } \\
\text { that pertain to matters } \\
\text { external to the } \\
\text { organization such as } \\
\text { compliance with } \\
\text { government } \\
\text { regulations, ecological } \\
\text { footprint, and internal } \\
\text { and external audits. }\end{array}$} & \multirow{3}{*}{$\begin{array}{l}\text { Coordination } \\
\text { forum with } \\
\text { DISNAKER, } \\
\text { East Jakarta } \\
\end{array}$} & 3 & \multirow[t]{3}{*}{6} \\
\hline & $\begin{array}{l}\text { Governance } \\
\text { (External) }\end{array}$ & & & & \\
\hline & & & & & \\
\hline
\end{tabular}




\subsection{Employee Opinion Data}

The majority employees (95.8\%) agree to continue WFH implementation combine with WFO and 2.8\% employees agree to continue Fully WFH implementation (total agree to continue WFH $=98.8 \%$ ) post Pandemic Covid-19 is shown in Figure 3.
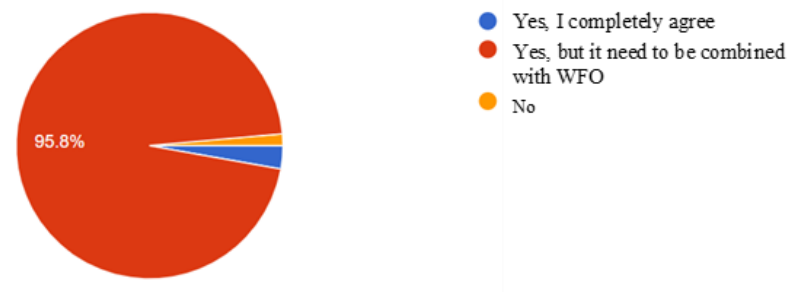

Figure 3 Employee opinion data

\subsection{Discussion}

1. $I^{\text {st }}$ Research Question: Does WFH correlate with $O E$ ?: It becomes very clear that the Work from Home method in this organization has a strong and positive correlation to Organizational Effectiveness. The dimension of Work from Home that use in this research in line with the Trisakti Soul concept which was eventually developed later into Panca Daya, belongs to one of the Indonesian educational hero, Mr. Ki Hajar Dewantara who acknowledged as Bapak Pendidikan Nasional Indonesia or $1^{\text {st }}$ minister of teaching/education. In Trisakti concept, Mr. Ki Hajar Dewantara stated that for optimizing people potential have to explore and develop: Cipta (Cognitive), Rasa (Affective), Karsa (Conative), Taqwa (Spiritual dimension) and Karya (Works dimension). Refer to the result of 1st hypothesis, it is very clear that The Panca Daya concept of Mr. Ki Hajar Dewantara implemented and demonstrated well in this organization. Table 1 is a strong evidence of the achievement of Karya/Works Dimension while Taqwa/Spiritual Dimension is a mandatory program for organization that have to be manage well as stated at SDSI (Strategic Direction and Strategic Implementation) document.

2. $2^{\text {nd }}$ Research Question: Are Employee condition (Having Children at Home, Home Internet Connection, Mobile Device) correlated with Organizational Effectiveness?: The fact that it is clear that "Having children at Home" as 1st Moderate variable support positive correlation between Work from Home and Organizational Effectiveness ( $\mathrm{R}$ Square 59.9\%), which is interesting because it is opposite from the research finding of Bloom et al. [7] and Rudnicka et al. [8] the fact that the existence of children at home can interfere Work from Home activity. The finding can be explained that in Indonesia, almost all families have assistants who can help solve household affairs such as preparing food, bathing children, washing clothes, ironing, etc. Another aspect which states that Indonesian culture tends to be happy to gather together under any circumstances [9].

3. $3^{\text {rd }}$ Research Question: Is there any difference perception between Superior and Subordinate toward implementation Work from Home method?: During WFH or others teleworking methods, there is classic issue that superior and subordinate having a different perspective to face it. Several reasons are possible to answer that finding. Cultural is one of important aspect that influence the behavior of the employee. There is strong Javanese/society cultural and value that may influence the employee, both superior and subordinate. "Nrima ing pandum, makaryo ing nyoto" (the society expected to accept all the result (that blessed by God) after hard working) is one of the values that influence the mind set and behavior [9].

4. $4^{\text {th }}$ Research Question: Is there any difference in perception between Superior and Subordinate toward Organization Effectiveness (OE)?: Analysis of perception between Superior and Subordinate toward OE, prove there were evidence: All the activities drive by the leaders who take more responsibility during Work from Home, because they got more leadership development programs.

\section{CONCLUSIONS}

1. To answer the $1^{\text {st }}$ research question: Yes. There is positive correlation between Work from Home and Organizational Effectiveness within the organization.

2. To answer the $2^{\text {nd }}$ research question: Yes. There are 3 variable that support positive correlation between Work from Home and Organizational Effectiveness, i.e.: Having Children at Home, Internet Home Connection and Mobile Device.

3. To answer $3^{\text {rd }}$ research question: No. There is no significant difference perception between Superior and Subordinate toward implementation of Work from Home.

4. To answer $4^{\text {th }}$ research question: Yes. There is significant difference perception between Superior and Subordinate toward Organizational Effectiveness.

\section{RECOMMENDATIONS}

\section{For Academic Purpose:}

a. To enrich the view about this topic in Indonesia because of the limitation of the study of Work from Home \& Organizational Effectiveness. 
b. It can be a literature for Work from Home analysis related Organizational Effectiveness.

c. Basis literature for longitudinal study about WFH correlation with OE.

d. Further research on the impact of the implementation of WFH during Pandemic Covid-19 on OE can be done using the concept of local wisdom, for example: Panca Daya concept by Ki Hajar Dewantara.

\section{For Practical Contribution:}

a. To get a complete picture of WFH impact to OE, further research can be carried out at any organization operated in Indonesia.

b. Further research on the correlation of WFH, OE and Organizational Structure can be carried out to determine resilient organization Program.

\section{AUTHORS' CONTRIBUTIONS}

Edhie Sarwono made contributions as first authors. Data was collected and analysed by Edhie Sarwono and Gembong Baskoro. All authors (Sumarsono, Dena Hendriana, and Henry Nasution) made contributions to the design of the study and the writing of the manuscript.

\section{ACKNOWLEDGMENTS}

Thank you, God, that I finished this research, and special thanks to Dr Gembong who is always give good direction, inspiration, and also challenge to freely explore various concept and knowledge, especially his approval on topics that relevant to the organization and very important to others professional organization that facing Pandemic Covid-19. Also special thanks to Dr. Sumarsono who always inspires to think systematically and introduce "slide model" to write the ideas quickly. A tremendous thank you to PT United Tractors Tbk which has become an interesting place to grow and become a professional life school. Last but not least, thank you to my colleagues Warno, Willy, Cipta, and Arif, you guys are awesome.

\section{REFERENCES}

[1] D. Ulrich, J. Younger, W. Brockbank, M. Ulrich, HR Transformation: Building Human Resources from the Outside In. New York: McGraw-Hill, 2009.

[2] W.A. Martz, Evaluating Organizational Effectiveness, Dissertations, Michigan: Western Michigan University, 2008.

[3] A. Guspa and T. Rahmi, Hubungan Antara Persepsi Terhadap Financial Reward, Hubungan Antar Persepsi, Jurnal RAP UNP, Vol. 5(1), 2014, pp.1-11.

[4] S. Azwar, Reliabilitas dan Validitas. Yogyakarta: Pustaka Pelajar, 2010.

[5] N.K. Malhotra, Marketing Research: An Applied Orientation, New York: Pearson, 2009.

[6] L.R. Kahle and N.K. Malhotra, Marketing Research: An Applied Orientation. Journal of Marketing Research, Vol. 31(1), February 1994, pp.137-139, doi: 10.2307/3151953.

[7] N. Bloom, J. Liang, J. Roberts, Z.J. Ying, Does Working from Home Work? Evidence from a Chinese Experiment, The Quarterly Journal of Economics, Vol. 130(1), February 2015, pp.165218, https://doi.org/10.1093/qje/qju032.

[8] A. Rudnicka, J.W. Newbold, D. Cook, M.E. Cecchinato, S.J.J. Gould, A.L. Cox, Eworklife: developing effective strategies for remote working during the COVID-19 pandemic, August 2020. Accessed on: July. 10, 2021. [Online]. Available: https://www.microsoft.com/enus/research/publication/eworklife-developingeffective-strategies-for-remote-working-during-thecovid-19-pandemic/

[9] N.A.T. Wulandari, Filosofi Jawa Nrimo Ditinjau Dari Sila Ketuhanan Yang Maha Esa, Jurnal Ilmiah Pendidikan Pancasila dan Kewarganegaraan, Vol. 2(2), 2017, pp. 132-138. doi: 10.17977/um019v2i2201. 